\title{
Terminal Sacrifice
}

National Cancer Institute

\section{Source}

National Cancer Institute. Terminal Sacrifice. NCI Thesaurus. Code C90465.

An indication that the subject was euthanized at the end of the study. 